\title{
K niektorých zásadám trestného stíhania právnických osôb v Slovenskej republike*
}

\section{Some Principles of Criminal Prosecution of Legal Entities in the Slovak Republic}

\author{
Ivan Šimovček ${ }^{* *}$
}

\begin{abstract}
Abstrakt
Autor sa v príspevku zaoberá problematikou zásad trestnébo stíhania právnických osôb, ktoré garantujú jeho zákennost'. Zásady upravené v procesných ustanoveniach Zákona o trestnej zodpovednosti právnických osôb upravijú zásady trestnébo stíhania právnickéch osôb len velmi všeobecne a rámcovo a daný zákon sa plne spolieha na jednotlivé procesné zásady obsiahnuté v ustanoveniach Trestného poriadku. Predpokladané výkladové a aplikačné problémy spojené s trestným stíhanim právnickéch osôb nepochybne vyvolajú $v$ budúcnosti potrebu podrobnejšej úpravy procesných zásad trestného stíbania právnických osôb, predovšetkým v problematike začatia trestnébo stíhania a dokazovania ich trestnej cinnosti.
\end{abstract}

\section{Klíčová slova}

Trestná zodpovednost’prámickeých osôb; zásada zacăatia trestnébo stíhania prámickej osoby; Zásada ne bis in idem.

\begin{abstract}
The author deals with the issue of the principles of criminal prosecution of legal persons, which guarantee its legality. The principles set out in the procedural provisions of the Criminal Liability Act regulate the principles of criminal prosecution of legal persons only very broadly and in a framework and the law relies fully on the individual procedural principles contained in the provisions of the Criminal Procedure Code. The supposed interpretation and application problems associated with criminal prosecution of legal entities will undoubtedly trigger the need in the future for a more detailed adjustment of the procedural principles of criminal prosecution of legal entities, especially the opening of criminal prosecution and evidencing of criminal offenses.
\end{abstract}

\section{Keywords}

Criminal Liability of Legal Persons; ne bis in idem Principle; the Principle of Criminal Prosecution of a Legal Person.

\section{Úvod}

Zákon č. 91/2016 Z.z. o trestnej zodpovednosti právnických osôb (d’alej len „Zákon o TZPO“) upravuje zásady a osobitosti trestného stíhania právnických osôb ${ }^{1}$ len

* Tento príspevok bola podporený Agentúrou na podporu výskumu a vývoja na základe Zmluvy č. APVV-16-0106.

** Prof. JUDr. Ivan Šimovček, CSc., Katedra trestného práva a kriminológie, Právnická fakulta, Trnavská univerzita v Trnave, Slovensko / Department of Criminal Law and Criminology, Faculty of Law, Trnava University in Trnava, Slovak Republic / E-mail: ivan.simovcek@truni.sk

1 \21 až \33 zákona č. 91/2016 Z.z. o trestnej zodpovednosti právnických osôb. 
rámcovo a bohužial' nie príliš podrobne, nakol'ko sa plne spolieha na jednotlivé zásady a procesné inštitúty obsiahnuté v ustanoveniach Trestného poriadku (d’alej len „TP“). ${ }^{2}$ Procesné ustanovenia Zákona o TZPO sú takto vo vzt'ahu k ustanoveniam Trestného poriadku primárne a ustanovenia Trestného poriadku sa uplatnia len za splnenia nasledovných podmienok:

- Ak Zákon o TZPO neobsahuje osobitnú procesnú úpravu.

- Ak to nie je z povahy veci vylúčené vzhl’adom na charakter právnických osôb. ${ }^{3}$

Zatial’ čo prvá podmienka nevyvoláva aplikačné problémy, v prípade druhej podmienky použitie resp. vylúčenie týchto ustanovení pri úprave trestného stíhania právnických osôb, môže vyvolat' celý rad aplikačných problémov vychádzajúcich zo správneho chápania a vymedzenia charakteru právnickej osoby.

Právnické osoby sú právom vytvorené „fiktívne osoby”, ktoré majú svoju právnu spôsobilost', spôsobilost' na právne a protiprávne úkony a spôsobilost' niest' trestnoprávnu zodpovednost'. Právnické osoby, proti ktorým sa vedie trestné konanie, majú zaručené právo na spravodlivý proces, t. j. majú právo, aby ich vec bola spravodlivo, verejne a v primeranej lehote prejednaná nezávislým a nestranným súdom, zriadeným zákonom.

Procesné zásady a garancie trestného konania proti právnickým osobám sú v podstate rovnaké ako v trestnom konaní proti páchatel'om - fyzickým osobám (zásada zákonnosti trestného stíhania, zásada prezumpcie neviny, zásada legality, zásada oficiality, zásada vyhl'adávacia, zásady verejnosti, bezprostrednosti a ústnosti, zásada vol'ného hodnotenia dôkazov, zásada zaistenia práva na obhajobu).

Procesná čast' Zákona o 'TZPO obsahuje špecifické ustanovenia o trestnom konaní proti právnickým osobám, upravujúce vzt'ah trestného konania ku konaniu o správnom delikte, zastupovanie právnickej osoby v trestnom konaní, právo na obhajobu, miestnu príslušnost', spoločné konanie proti právnickej a fyzickej osobe, doručovanie písomností, poradie výsluchu a záverečných rečí obžalovaného - fyzickej osoby a zástupcu obžalovanej právnickej osoby na hlavnom pojednávaní, povinnosti právnickej osoby v súvislosti s jej zrušením, zánikom a zmenou, zaist’ovacie opatrenia a spôsob výkonu trestov, uložených právnickým osobám.

\section{Začatie trestného stíhania právnických osôb a dokazovanie.}

Vo svojom príspevku by som chcel sústredit’ len na ustanovenia Zákona o TZPO upravujúce zásady začatia trestného stíhania právnických osôb, ktoré môžu spôsobit' výkladové a najmä aplikačné problémy.

2 Zák. č. 301/2005 Z.z. Trestný poriadok v znení noviel.

3 ZÁHORA, J. Trestná zodpovednost' právnických osôb. In: Rekodifikácia trestnébo práva: zborník príspevkov z. celośtátnej konferencie s medzinárodnou účast’ou konanej dňa 17. mája 2004. Bratislava: Akadémia PZ, 2004, s. 67 a nasl. 
Začatie trestného stíhania proti právnickej osobe ${ }^{4}$ bráni tomu, aby o tom istom skutku proti tej istej právnickej osobe prebiehalo konanie o správnom delikte. Trestné stíhanie proti právnickej osobe nemožno začat', a ak už bolo začaté, nemožno v ňom pokračovat' a musí byt' zastavené, ak skoršie konanie pre ten istý skutok proti tej istej právnickej osobe skončilo právoplatným rozhodnutím o správnom delikte a toto rozhodnutie nebolo zrušené. Pri začatí trestného stíhania právnickej osoby bolo treba vyriešit' otázku premlčania skutku, predstavujúceho správny delikt. Ak osobitné predpisy ${ }^{5}$ ustanovujú lehotu pre zánik zodpovednosti právnických osôb za správny delikt, nezapočítava sa do jej plynutia čas, počas ktorého sa pre ten istý skutok viedlo trestné konanie podla Zákona o TZPO.

Osobitne je tu vymedzený vzt’ah trestného a správneho konania vedeného pre ten istý skutok proti tej istej právnickej osobe. Začatie trestného stíhania v tomto prípade vytvára tzv. prekážku litispendencie. Začatím trestného stíhania proti právnickej osobe sa rozumie vznesenie obvinenia proti právnickej osobe, nepôjde o začatie trestného stíhania tzv. vo veci. ${ }^{6}$ Začatie trestného stíhanie proti právnickej osobe bráni tomu, aby proti rovnakej právnickej osobe za ten istý skutok (totožnost' osoby a skutku) bolo vedené súčasne aj správne konanie. Správne konanie vedené voči právnickej osobe pre ten istý skutok, ktorý má znaky správneho deliktu, sa prerušuje a nemožno v ňom pokračovat', ak sa vo veci pre ten istý skutok začne alebo vedie trestné stíhanie voči právnickej osobe. Osobitost' spočíva $\mathrm{v}$ tom, že ani začatie trestného stíhania nebráni vykonaniu iných opatrení správneho charakteru, akými sú uloženie nútenej správy alebo bankového dohladu. Takto je umožnené správnemu orgánu aj počas prebiehajúceho trestného konania vykonat' v zmysle iných právnych predpisov opatrenia, ktoré nie sú sankciou, ale majú voči právnickej osobe nápravný charakter (napríklad nútená správa). ${ }^{7}$

Začatie trestného stíhania (tzv. vo veci) je nevyhnutnou podmienkou na to, aby bolo možné vykonávat' dokazovanie. ${ }^{8}$ Vymedzenie dôkazov, dôkazných prostriedkov a procesu dokazovania sa až na malé výnimky plne riadi ustanoveniami VI. hlavy TP. Nazdávam sa, že justičná prax prinesie potrebu osobitného upravenia problematiky

4 \ 21 zákona č. 91/2016 Z. z. o trestnej zodpovednosti právnických osôb.

5 \ 19 ods. 4 zákona č. 747/2004 Z. z. o dohl’ade nad finančným trhom a o zmene a doplnení niektorých zákonov v znení neskorších predpisov, \50 ods. 10 zákona č. 483/2001 Z. z. o bankách v znení neskorších predpisov.

6 \199 ods. 1 zákona č. 301/2005 Z. z. Trestného poriadku.

7 Zákon č. 483/2001 Z.z. o bankách a o zmene a doplnení niektorých zákonov v znení neskorších predpisov.

8 POLÁK, P. Procesné práva obvinenej právnickej osoby. In: JELÍNEK, J. a kol. Trestni odpovédnost právnických osob v České republice - bilance a perspektivy. Praha: Leges, 2013, s. 256 a nasl.

9 \24 ods. 3 Zákona č. 91/2016 Z. z. o trestnej zodpovednosti právnických osôb. Ak majú byt’ v priebehu spoločného konania vedeného proti fyzickej osobe a právnickej osobe vykonávané úkony trestného konania vo vzt'ahu k obom týmto osobám, uskutočňujú sa spravidla najprv vo vzt'ahu k fyzickej osobe. 
dokazovania $\mathrm{v}$ trestnom konaní proti právnickým osobám, osobitne v otázkach zaist'ovacích procesných úkonov a zabezpečovania informácií potrebných pre trestné konanie. 'Trestné stíhanie je oprávnený začat' orgán činný v trestnom konaní vydaním uznesenia alebo vykonaním zaist'ovacieho, neopakovatel'ného alebo neodkladného úkonu ( 199 TP). Osobitost' je zvýraznená tým, že forma trestného stíhania právnických osôb je výlučne vyšetrovanie, ${ }^{10}$ t. j. neprichádza do úvahy vykonat’ skrátené vyšetrovanie v prípade trestného stíhania právnických osôb. Daného vyplýva, že okrem prokurátora začat' trestné stíhanie právnickej osoby je výlučne oprávnený vyšetrovatel’ Policajného zboru a vyšetrovatel' finančnej správy, ak ide o trestné činy spáchané v súvislosti s porušením colných predpisov alebo daňových predpisov v oblasti dane z pridanej hodnoty pri dovoze a spotrebných daní. ${ }^{11}$

Formou začatia trestného stíhania právnických osôb je vydanie jedného uznesenia o začatí trestného stíhania a vznesení obvinenia (\206 ods. 2 TP), iný spôsob začatia trestného stíhania viac menej neprichádza do úvahy.

Prípravné konanie nadväzuje na výsledky postupu pred začatím trestného stíhania. Je to úsek trestného konania od začatia trestného stíhania do podania obžaloby, návrhu na schválenie dohody o vine a treste alebo do právoplatnosti rozhodnutia orgánu činného $\mathrm{v}$ trestnom konaní. Účelom prípravného konania je čo najrýchlejšie obstarat' dôkazy potrebné pre rozhodnutie, či sa má podat’ obžaloba, príp. návrh na schválenie dohody o vine a treste, alebo či má orgán činný v trestnom konaní ukončit' trestné konanie už v tomto štádiu niektorým z rozhodnutí vo veci samej (napr. uznesením o schválení zmieru). Základným ciel’om prípravného konania je splnit' jeho zabezpečovaciu a verifikačnú funkciu.

Dôraz sa kladie na zabezpečenie dôkazov, resp. prameňov dôkazov potrebných pre konanie pred súdom (najmä pre hlavné pojednávanie) ale aj pre iné rozhodnutia v prípravnom konaní. Vo vzt'ahu ku konaniu pred súdom má preto prípravné konanie predbežnú povahu, to znamená, že t’ažisko dokazovania má spočívat'v konaní pred súdom a v prípravnom konaní sa majú obstarat' dôkazy, resp. pramene dôkazov, ktoré by sa mohli vykonat' pred súdom. Je zrejmé, že od kvality dokazovania v prípravnom konaní často závisí úspešnost' samotného konania pred súdom.

Verifikačná funkcia prípravného konania zabraňuje tomu, aby boli pred súd postavené nevinné osoby. Orgány činné $\mathrm{v}$ trestnom konaní sú povinné obstarávat' dôkazy svedčiace $\mathrm{v}$ prospech obvineného $\mathrm{s}$ rovnakou starostlivost'ou ako $\mathrm{v}$ jeho neprospech, tak aby umožnili súdu spravodlivé rozhodnutie. Verifikačná funkcia predchádza tomu, aby sa na súdy dostávali nedostatočne objasnené prípady.

10 Zákonom č. 91/2016 Z.z. o trestnej zodpovednosti právnických osôb bol rozšírený \200 ods. 2 Trestného poriadku vložením nového písmena c), ktoré stanovilo, že vyšetrovanie sa vykonáva vtedy, ak ide o trestné konanie proti právnickej osobe.

11 \ 10 ods. 8, písm. a) a b) zákona č. 301/2005 Z. z. Trestného poriadku. 
Vznesenie obvinenia (\206 ods. 1 TP) umožňuje trestne stíhat' právnickú osobu pre určitý skutok, ktorý napíňa znaky určitého trestného činu. Proti tejto osobe ako obvinenému možno postupovat' podl’a procesných ustanovení Zákona o 'TZPO a súčasne využívat' procesné prostriedky podl'a 'Trestného poriadku za splnenia podmienky, že ich použitie nebude vylúčené vzhl’adom na charakter právnických osôb ${ }^{12}$. Obvinená právnická osoba má právo uplatnit' všetky práva podl'a 'Trestného poriadku (\$33 a nasl. TP) a podla osobitných ustanovení o trestnom stíhaní tohto zákona ( $\int 21$ a nasl. TZPO). O tom, že bolo začaté trestné stíhanie právnickej osoby je orgán činný v trestnom konaní povinný informovat' príslušné orgány verejnej moci ( $\$ 23$ TZPO).

Zákaz dvojakého trestného stíhania a potrestania za totožný skutok (ne bis in idem) je ústavnou zásadou (čl. 50 ods. 5 Ústavy a čl. 4 ods. 1 Protokolu č. 7 Európskeho dohovoru). Zmyslom danej zásady je zabránit' opakovaniu trestného stíhania za rovnaký spáchaný skutok, t. j. nikoho nemožno trestne stíhat' za čin, za ktorý bol už právoplatne odsúdený alebo oslobodený spod obžaloby. Táto zásada však nevylučuje uplatnenie mimoriadnych opravných prostriedkov v súlade so zákonom.

'Trestné stíhanie nemožno začat', a ak už bolo začaté, nemožno v ňom pokračovat' a musí byt' zastavené, ak tak stanovuje medzinárodná zmluva [ 9 ods. 1 písm. g) TP]. Podl'a čl. 4 ods. 1 Protokolu č. 7 Európskeho dohovoru nikto nemôže byt' stíhaný alebo potrestaný $\mathrm{v}$ trestnom konaní $\mathrm{v}$ právomoci toho istého štátu za trestný čin, za ktorý už bol oslobodený alebo odsúdený konečným rozsudkom podl'a zákona a trestného poriadku tohto štátu. ${ }^{13} \mathrm{Ak}$ sa týka daný dôvod len niektorého z čiastkových útokov pokračovacieho trestného činu, nebráni to tomu, aby sa vo zvyšnej časti takého činu viedlo trestné stíhanie ( 9 ods. 2 TP).

Zásada ne bis in idem platí pre právnické osoby v prípadoch súbehu správneho deliktu a trestného činu spáchaného právnickou osobou ${ }^{14}$. V prípade trestného stíhania fyzických osôb nebola táto zásada vždy akceptovaná bez výhrad (R 47/1989). V zmysle judikatúry Európskeho súdu pre l’udské práva sa zásada ne bis in idem uplatní pri právnických osobách aj na niektoré delikty, ktoré sú vo vnútroštátnom práve zmluvných štátov kvalifikované ako správne delikty. Právoplatné rozhodnutie v správnom konaní voči právnickej osobe, vydané pre ten istý skutok, tvorí prekážku veci rozhodnutej, ak takéto rozhodnutie nebolo predpísaným spôsobom zrušené ${ }^{15}$.

12 DESET, M. Prostriedky z̧abezpečovania informácii dôležitých pre trestné konanie a právo na súkromie. Bratislava: Typy Universitatis Tyrnaviensis a Veda, 2016, s. 74 a nasl.

13 GŘIVNA, T. Ke vztahu trestního řízení proti právnické osobě a řízení o správním deliktu téže osoby pro týž skutek. In: JELÍNEK, J. a kol. Trestni odpovédnost právnickéch osob v České republice - bilance a perspektivy. Praha: Leges, 2013, s. 194 a nasl.

14 JELÍNEK, J. a J. HERCZEG. Zákon o trestni odpovédnosti právnických osob. Komentár s judikaturou. 2. vyd. Praha: Leges, 2013, s. 144 a nasl.

15 Pozri aj judikatúru Najvyššieho súdu R 23/1972, R 33/1974, R 47/1989. 
Nie každé rozhodnutie $\mathrm{v}$ trestnom konaní tvorí prekážku v zmysle zásady ne bis in idem. Pri odložení veci podl’a \66 ods. 3 písm. a) priestupkového zákona sa nevydáva žiadne formálne rozhodnutie, čiže nejde o konečný oslobodzujúci alebo odsudzujúci rozsudok podl'a čl. 4 Protokolu č. 7 Dohovoru, ktorý by tvoril prekážku veci rozhodnutej. $\mathrm{V}$ danom prípade nie je nasledujúce trestné stíhanie toho istého obvineného pre ten istý skutok neprípustné. ${ }^{16}$

Zásada ne bis in idem - zákaz dvojitého súdenia a potrestania za ten istý čin (skutok) podl’a čl. 4 Protokolu č. 7 Dohovoru bráni tiež trestnému stíhaniu a odsúdeniu toho, proti ktorému predchádzajúce priestupkové konanie o tom istom skutku trestnoprávnej povahy meritórne skončilo právoplatným rozhodnutím príslušného správneho orgánu, a to vrátane blokového konania. Vylúčit’ ochranu proti novému procesu s poukázaním na zásadu ne bis in idem nemôže ani tá skutočnost', že príčinou prvého prerokovania skutku v blokovom priestupkovom konaní bola jeho nesprávna kvalifikácia ako priestupku, hoci naplňoval znaky trestného činu. Právne bezvýznamné je aj to, prečo došlo k novému konaniu a rozhodnutiu v danej veci, hoci nebolo zrušené predchádzajúce rozhodnutie o totožnom skutku (čine). ${ }^{17}$

Prekážka veci právoplatne rozhodnutej (exceptio rei iudicatae) predpokladá zistenie, že v novom konaní ide o ten istý skutok. Hoci sa v blokovom konaní nevydáva písomné rozhodnutie príslušného orgánu, z ktorého by bol zrejmý presný opis skutku, je z dokladu o skončení blokového konania (pokutového bloku) v zásade zistitel'né, pre aký druh priestupku bolo blokové konanie vedené. Ak vznikne pochybnost’ o vymedzení skutku, pre ktorý bol páchatel' v blokovom konaní uznaný za vinného, treba vykonat' potrebné dokazovanie, na základe ktorého bude po zhodnotení všetkých vykonaných dôkazov skutok, ktorý naplňuje príslušný priestupok, zistený a vymedzený. ${ }^{18}$

Zásada „ne bis in idem“ vyjadrujúca zákaz niekoho stíhat’ alebo potrestat' dvakrát za tú istú vec, je neodmyslitel'nou a nespochybnitel'nou súčast'ou spravodlivého procesu. Zásada „,ne bis in idem“ platí bez výnimky. Výkladový problém spočíva v stotožňovaní alebo rozlišovaní pojmu skutok tvorený čiastkovými útokmi pokračujúceho trestného činu, ako ho používa trestný poriadok. Ak sa vychádza z predpokladu, že zmyslom a účelom ústavnej zásady ne bis in idem je zabránit' opakovanému stíhaniu trestne zodpovednej osoby za rovnaké faktické konanie, potom v špecifickom prípade pokračujúceho trestného činu možno stotožnit' pojem čin s pojmom čiastkový útok. ${ }^{19}$

Ak trestné stíhanie proti právnickej osobe bolo zastavené z dôvodu, že v danej veci ide o priestupok, mohlo by dôjst’ v čase trestného konania k premlčaniu lehoty pre uplatnenie

\footnotetext{
16 Rozsudok Najvyššieho súdu ČR zo dňa 17. februára 2011, sp. značka 6 Tdo 152/2011.

17 Rozsudok Najvyššieho súdu ČR zo dňa 25. februára 2009. sp. značka 5 Tdo 13/2009.

18 Rozsudok Najvyššieho súdu ČR zo dňa 25. februára 2009. sp. značka 5 Tdo 13/2009.

19 Rozsudok Ústavného súdu ČR zo dňa 9. júla 2003, sp. značka PI ÚS 6/03.
} 
správnej zodpovednosti za daný skutok. Preto Zákon o TZPO osobitne výslovne určuje pre túto dobu tzv. spočívanie lehoty. Ak osobitné predpisy ustanovujú lehotu pre zánik zodpovednosti právnických osôb za správny delikt, nezapočítava sa do jej plynutia čas, počas ktorého sa pre ten istý skutok viedlo trestné konanie podl'a tohto zákona.

'Totožnost' skutku nemožno chápat' dogmaticky. Pre totožnost' skutku nie je nevyhnutné, aby bola zachovaná zhoda všetkých skutkových okolností. Totožnost' skutku je zachovaná aj vtedy, ak existuje čiastočná, ale podstatná zhoda skutkových okolností. Ide teda o také skutkové okolnosti, ktoré charakterizujú konanie alebo následok z hl’adiska právnej kvalifikácie.

Pre určenie totožnosti skutku Európsky súd pre l'udské práva (d’alej „ESL’P“) vytýčil tri tzv. Engelovské kritériá (Rozsudok ESL’P zo dňa 8. júna 1976. Engel a ostatni v. Holandsko, č. 5100/71, 5101/71, 5102/71, 5354/72, 5370/72).

Konštatovanie totožnosti skutku vychádza z posúdenia troch tzv. Engelovských kritérií. Prvým kritériom je skutočnost', že predmetný čin je v rámci právneho poriadku štátu považovaný za trestný. Pod trestnost'ou sa rozumieme nielen trestnoprávne kritérium ale aj administratívnoprávne. Prvým kritériom je teda právna kvalifikácia. Druhým kritériom je povaha deliktu, čiže je nevyhnutné posudzovat', či daným deliktom bola porušená právna norma adresovaná neurčitému okruhu adresátov alebo naopak len špecifickej skupine adresátov. Tretím kritériom je povaha a stupeň závažnosti sankcie, ktorú možno uložit' za takýto delikt. Delikt je možné podradit' pod čl. 4 dodatkového protokolu č. 7 Európskeho dohovoru v tom prípade, že porušená právna norma je adresovaná neurčitému okruhu osôb a uložená sankcia má aspoň z časti preventívno-represívny charakter. $^{20}$

Európsky súd pre l'udské práva tiež uviedol, že za jeden skutok treba považovat' prípady, ked' sa konkrétne skutkové okolnosti týkajú toho istého obžalovaného a sú neoddelitel'ne spojené v čase a priestore. V prípade totožnosti skutku je právna kvalifikácia irelevantná. ${ }^{21}$ Rovnako Európsky súdny dvor konštatoval, že článok 54 Dohovoru k vykonaniu Schengenskej dohody zo dňa 14. júna 1985 musí byt' vykladaný v tom zmysle, že relevantným kritériom pre uplatnenie tohto článku je kritérium totožnosti skutkovej podstaty činu chápanej ako existencia súboru skutočností, ktoré sú vzájomne neoddelitel’ne späté, bez ohl'adu na právnu kvalifikáciu tohto činu alebo na chránenom právnom záujme. ${ }^{22}$

20 Rozsudok ESL’P zo dňa 8. júna 1976. Engel a ostatni v. Holandsko, č. 5100/71, 5101/71, 5102/71, 5354/72, $5370 / 72$.

21 Rozsudok ESL’P zo dňa 10. februára 2009. Zolothukin v. Rusko, č. 14939/03.

22 Rozsudok ESD. Van Esbroeck (C-436/04); Rozsudok ESD. Van Straaten (C-150/05); a Rozsudok ESD. Kraaijenbrink (C-367/05). 
Výkladové nejasnosti uplatňovania zásady ne bis in idem priniesol iný rozsudok ESLP. ${ }^{23}$ Tento prípad sa týkal dvoch daňových poplatníkov, ktorí tvrdili, že boli stíhaní a dvakrát potrestaní - v správnom a trestnom konaní - za ten istý trestný čin, nakol'ko daňové sankcie, ktoré im uložili daňové orgány zaplatili a potom boli obžalovaní a odsúdení za tie isté skutky v trestnom konaní. V tomto prípade vel'ká komora ESL'P rozhodla, že nedošlo k porušeniu článku 4 Protokolu č. 7. Pokial ide o otázku, či prvá séria konaní bola „trestná“, vel'ká komora ESL’P pripomenula, že rozsudok Sergeja Zolotukhina z 10. februára 2009 nebolo možné v tejto veci výslovne aplikovat’ a Súdny dvor Európskej únie úmyselne v tomto rozsudku zvolit’ tzv. „Engelovské kritéria““ ako model na určenie, či príslušné konanie bolo na tieto účely „trestné“ v zmysle článku 4 protokolu č. 7. Vel'ká komora ESL'P sa necítila oprávnená popriet’ takúto analýzu v prejednávanej veci, ked’že existovali skutočne závažné úvahy v prospech takejto vol’by, avšak v tejto súvislosti poznamenala, že zásada nen bis in idem sa týka najmä riadneho procesu, ktorý je predmetom konania v zmysle článku 6 (právo na spravodlivé súdne konanie) Dohovoru a menej sa týka veci podstaty trestného práva v zmysle článku 7 (niet trestu bez práva) Dohovoru. Z hl’adiska konzistentnosti výkladu Dohovoru ako celku vel'ká komora ESL’P by považovala za vhodnejšie, aby uplatnitel'nost' zásady ne bis in idem vychádzala z presnejších kritérií než sú tzv. „Engelovské kritéria“.

V podobnom zmysle zaujal stanovisko Najvyšší súd Českej republiky, ktorý vo svojom rozhodnutí ${ }^{24}$ konštatoval, že právoplatné rozhodnutie, ktorým končí jedno zo súbežných či postupne vedených daňových a trestných konaní, ktoré sú konaním trestnoprávnej povahy v zmysle tzv. Engel kritérií, netvorí prekážku veci rozhodnutej s účinky ne bis in idem, ak je medzi daňovým a trestným konaní nielen dostatočne úzka vecná súvislost', ale súčasne aj súvislost’ časová. Medzi významné faktory určujúce dostatočne úzku vecnú súvislost' patria skutočnosti, či obidve samostatné konania sledujú vzájomne sa doplňujúci ciel', t. j. či sa týkajú, nielen len in abstracto ale súčasne in concreto rôznych aspektov daného protiprávneho konania, či je kombinácia daných konaní predvídatel'ným následkom, a to ako právne, tak fakticky. Ciel’om je zabránenie nadmerného zat’aženia dotknutej osoby v danom konaní. Súd musí prihliadnut' pri určení druhu trestu a jeho rozsahu na právoplatné rozhodnutie finančného úradu o povinnosti uhradit' pokutu za vyrubenie dodatočnej dane a v odôvodnené rozhodnutia vysvetlit', ako táto okolnost' bola zohl’adnená.

Osobitosti začatia trestného stíhania právnických osôb možno vidiet’ aj v inštitúte upovedomenie o začatí a skončení trestného stíhania (\$2 23 Zákona o TZPO), kde povinnost' informovat' pri začatí trestného stíhania je výrazne širšia než v prípade trestného stíhania fyzických osôb. O začatí trestného stíhania proti právnickej osobe upovedomí policajt toho, kto vedie obchodný register alebo iný zákonom určený register, zápisom v ktorom

23 Rozsudok ESL’P zo dňa 15. novembra 2016, vo veci A. a B. v. Nórsko, č. 24130/11 a 29758/11.

24 Rozsudok Najvyššieho súdu ČR zo dňa 4. januára 2017, sp. značka 15Tdo 832/2016. 
právnická osoba vzniká. Rovnako upovedomí aj príslušný orgán dohl’adu alebo núteného správcu, ak je právnická osoba v nútenej správe podl’a osobitných predpisov ${ }^{25}$, orgán udel’ujúci licenciu alebo povolenie k činnosti tejto právnickej osoby.

O začatí trestného stíhania proti právnickej osobe pre trestný čin spáchaný v súvislosti s pomocou a podporou poskytovanou $z$ fondov Európskej únie podl’a osobitného predpisu $^{26}$ policajt upovedomí aj Úrad vlády Slovenskej republiky a Ministerstvo financií Slovenskej republiky a pre trestný čin spáchaný v súvislosti s verejným obstarávaním aj Úrad pre verejné obstarávanie a Ministerstvo financií Slovenskej republiky.

Orgány činné $v$ trestnom konaní a súdy sú povinné upovedomovat' príslušné štátne orgány, ktoré vedú registre, do ktorých zápisom právnická osoba vzniká a štátne orgány dohl'adu o začatí trestného stíhania voči právnickej osobe. Distribúcia týchto informácií je dôležitá z hl'adiska riadneho výkonu štátnej správy a naplnenia zmyslu právnej úpravy trestnej zodpovednosti právnických osôb.

Upovedomovanie orgánov, ktoré vedú príslušné registre, je dôležité z hl'adiska aplikácie \25 zákona o TZPO, podl’a ktorého zmena, zrušenia alebo zánik právnickej osoby po začatí trestného stíhania právnickej osoby podlieha súhlasnému rozhodnutiu súdu. Takéto obmedzenie trvá až do skončenia trestného stíhania. Upovedomenie orgánov štátneho dohl'adu je dôležité z hl'adiska výkonu oprávnení týchto orgánov rozhodovat' o platnosti, d’alšom trvaní, prípadne zrušení udeleného oprávnenia (licencie, povolenia a pod.).

Povinnost' upovedomenia Úradu vlády Slovenskej republiky o trestnom stíhaní právnickej osoby pre trestný čin spáchaný v súvislosti s pomocou a podporou poskytovanou z fondov Európskej únie vyplýva z plnenia záväzkov Slovenskej republiky z právnych aktov Európskej únie [nariadenie č. 1302/2008 o centrálnej databáze vylúčených subjektov, nariadenie č. 1303/2013, ktorým sa stanovujú spoločné ustanovenia o Európskom fonde regionálneho rozvoja, Európskom sociálnom fonde, Kohéznom fonde, Európskom pol’nohospodárskom fonde pre rozvoj vidieka a Európskom námornom a rybárskom fonde a ktorým sa stanovujú všeobecné ustanovenia o Európskom fonde regionálneho rozvoja, Európskom sociálnom fonde, Kohéznom fonde a Európskom námornom a rybárskom fonde, a ktorým sa zrušuje nariadenie Rady (ES) č. 1083/2006]. Začatie trestného stíhania proti právnickej osobe predstavuje prekážku jej zmeny alebo zrušenia bez súhlasu prokurátora alebo predsedu senátu. Ak je k zániku alebo zmene právnickej osoby potrebný zápis do zákonom určeného registra (『 2 zákona

25 Napríklad \53 až 62 zákona č. 483/2001 Z. z. o bankách a o zmene a doplnení niektorých zákonov v znení neskorších predpisov, $\int 147$ až 155 zákona č. 39/2015 Z. z. o poist’ovníctve a o zmene a doplnení niektorých zákonov.

26 Zákon č. 528/2008 Z. z. o pomoci a podpore poskytovanej z fondov Európskeho spoločenstva v znení neskorších predpisov. Zákon č. 292/2014 Z. z. o príspevku poskytovanom z európskych štrukturálnych a investičných fondov a o zmene a doplnení niektorých zákonov. 
č. 530/2003 Z.z. o obchodnom registri), predseda senátu upovedomí orgán verejnej moci, ktorý takýto register vedie, o skončení vykonávacieho konania.

\section{Záver}

Na záver možno konštatovat', že zásady upravené v procesných ustanoveniach Zákona o trestnej zodpovednosti právnických osôb upravujú zásadu začatia trestného stíhania právnických osôb len vel'mi všeobecne a rámcovo a daný zákon sa plne spolieha na jednotlivé procesné zásady obsiahnuté v ustanoveniach Trestného poriadku. Výkladové a aplikačné problémy spojené s trestným stíhaním právnických osôb, dokumentované aj nejednotnou európskou judikatúrou nepochybne vyvolajú v budúcnosti potrebu podrobnejšej úpravy procesných zásad začatia trestného stíhania právnických osôb. 